\title{
Інформаційна діяльність міжнародної організації «Репортери без кордонів» в Україні
}

\author{
Віталій Гандзюк, \\ канд. н. із соц. комунік., доц. \\ Вінницький державний \\ педагогічний університет імені \\ Михайла Коцюбинського \\ вул. Острозького, 32, \\ 21000, Вінниця, Україна \\ e-mail:vgandz@i.ua \\ (c) Гандзюк В., 2018
}

У статті з'ясовано позицію провідних країн світу щодо закріплення питання захисту свободи слова на законодавчому рівні, проаналізовано інформаційну діяльність та конщептуальні засади функціонування неурядової міжнародної організації «Репортери без кордонів» (РБК) в Україні.

Ключові слова: свобода слова, демократичне суспільство, інформаційна діяльність, «Репортери без кордонів»

\section{Постановка проблеми}

Однією з найважливіших умов існування будь-якого демократичного суспільства $€$ вільне функціонування незалежних ЗМІ як одного 3 інститутів демократії. Засоби масової інформації повинні гарантувати вільний обмін інформацією, забезпечувати індивідуальне й колективне право на висловлювання ідей і захист інтересів. Право людини на комунікацію, свободу слова, вільне вираження ідей і доступ до інформації визнається у конституціях понад 142 країн світу.

\section{Актуальність}

Кожна країна тлумачить свободу слова по-своєму, залежно від національних традицій і звичаїв, культурних і моральних цінностей нації, стереотипів тощо. В Австрії, Канаді, Нідерландах, Німеччині, Норвегії, США, Франції та Швеції свобода слова й преси закріплена в конституціях. У Німеччині та Іспанії вважається, що представники преси мають найбільші права збирати й поширювати інформацію, і ці привілеї є наслідком особливої ролі ЗМІ у формуванні суспільної думки та служінні національним інтересам. Щодо законодавства про 3МI, то окремий закон про пресу мають тільки Австрія, Швеція, Україна (на відміну від таких країн, як Австралія, Канада, Нідерланди, Норвегія, Іспанія, Велика Британія та США). У Швеції такий закон має навіть конституційний статус. У Німеччині існує низка федеральних законів 
про пресу, які складені за одним зразком, у Франції також діє кілька таких законів [2, 62].

Виклад основного матеріалу

Свобода вираження поглядів була визнана однією з фундаментальних демократичних цінностей, необхідних для мирного співіснування націй, коли після Другої світової війни Генеральна Асамблея ООН одностайно прийняла Загальну декларацію прав людини (10 грудня 1948 року). Таким чином, свободі вираження поглядів було надано найвищого статусу в Загальній декларації шляхом закріплення її в преамбулі як однієї з чотирьох невід’ємних. Це також закріплено у статті 19, в якій стверджується: «Кожна людина має право на свободу переконань і на вільне їх вираження; це право передбачає свободу безперешкодно дотримуватися власних переконань і свободу шукати, одержувати та поширювати інформацію та ідеї будь-якими засобами і незалежно від державних кордонів» [4, 153].

Загальна декларація прав людини стала визначним історичним документом, в якому закріплені загальні визначення людської гідності і людських цінностей. Декларація є мірилом досягнень всіх народів і всіх країн в частині пошани і дотримання міжнародних стандартів у сфері прав людини.

31 грудня 1994 р. 128 країн світу, зокрема й Україна, ратифікували МПГПП (Міжнародний пакт про громадські та політичні права). Тому український уряд юридично зобов'язаний дотримуватись положень МПГПП, де стверджується: «Кожна людина має право на вільне вираження своєї думки; це право включає свободу шукати, одержувати i поширювати будь-яку інформацію та ідеї, незалежно від державних кордонів, усно, письмово чи за допомогою друку або художніх форм вираження чи іншими способами на свій вибір» [5, 154].

Щодо Ради Європи, то вона напрацювала широку систему права, юриспруденції та стандартів щодо свободи слова, доступу до інформації та пов'язаних із ними прав на мирні збори і об'єднання. Основним законодавчим актом Ради Європи є Конвенція про захист прав і основних свобод людини, більш відома під назвою Європейська конвенція з прав людини (ЄКПЛ). Це найдавніший з міжнародних договорів про права людини (вона була прийнята в 1950 році та набула чинності у 1953 р.), і процедури її впровадження є найбільш розвинутими [3, 245].

До інших прав, що стосуються свободи слова, належить право на повагу до конфіденційності кореспонденції та телефонних розмов; право на свободу думки, совісті та релігії; право брати участь у діяльності профспілок.

Свобода преси є однією з важливих гарантій інформаційної безпеки, оскільки вона забезпечує доступ громадян до повної, всебічної та достовірної інформації, захищає громадську та індивідуальну 
свідомість від впливу пропаганди та інших форм маніпулювання, стимулює накопичення, оновлення та передачу інформації в середині соціальної системи. І в цьому сенсі інформаційна безпека повинна розглядатися як сполучна ланка між політикою забезпечення національної безпеки та політикою розвитку інформаційної інфраструктури вільного суспільства.

За останні два десятиліття історія показує розширення прав і можливостей людини на основі вільного потоку ідей і доступу до інформації та знань. Ця еволюція супроводжується багатьма резолюціями і заявами, офіційно зробленими міжнародною недержавною організацією захисту прав людини «Репортери без кордонів», яка оберігає свободу слова у всьому світі, сприяє свободі плюралістичних і незалежних 3MI, проводить боротьбу з цензурою та виступає за звільнення журналістів, які потрапили за грати під час виконання їхніх професійних обов'язків.

Потенційні можливості України, її геополітичне розташування у східноєвропейському регіоні, де нині відбуваються складні і суперечливі процеси, змушують закордонні засоби масової інформації поновому поставитись до висвітлення подій національного й міжнародного змісту.

Наразі Україна йде шляхом поступової інтеграції до євроатлантичних структур. Це вимагає передусім формування нового політичного й економічного мислення. 3 іншого боку, глобальні соціально-економічні перетворення у світі теж безпосередньо впливають на рівень свободи всіх учасників інформаційного процесу.

Зацікавленість розвитком подій в Україні з боку «Репортерів без кордонів» вперше була зафіксована наприкінці 1991 р., коли Комуністична партія України втратила монополію на засоби масової інформації, зокрема пресу. Тоді в Україні було ліквідовано цензуру й проголошено свободу слова.

За офіційними даними «Репортерів без кордонів», у 1991 р. одного журналіста було вбито, на дев'ятьох здійснено напади. У 1994 р. було вбито трьох журналістів, семеро були травмовані. У 1997 р. вбито чотирьох журналістів, ще двадцять вісім - травмовано. За 2001 р. двох журналістів було вбито і на вісімнадцятьох були скоєні напади. Загиблі журналісти здебільшого працювали над матеріалами, що містили обвинувачення на адресу правоохоронних органів або впливових політичних чи економічних структур загальнонаціонального або місцевого рівня.

«Репортери без кордонів» вкрай гостро критикували дії, що стосуються справи Г. Гонгадзе. Не сподіваючись на зусилля української влади щодо ведення цієї справи, РБК наприкінці 2003 р. провели незалежне розслідування. Представник РБК на підготовчій зустрічі 
робочої комісії наголосив, що після понад трьох років розчарувань та безуспішних спроб домогтися результату, правоохоронні органи повинні знайти переконливі відповіді на запитання щодо загибелі Г. Гонгадзе й притягнути убивць та замовників злочину до суду.

Також необхідно зазначити, що Україна у 2003 р. посідала 133 місце за класифікацією стану свободи слова у світі. У 2002 р. країна була у цьому рейтингу на 112 місці, а зміна позиції у переліку пояснювалася тим, що список досліджуваних країн порівняно з 2002 р. збільшився 3 139 до 166 держав.

Під час висвітлення президентських виборів 2004 р. та Помаранчевої революції РБК написали відкритого листа новообраному Президенту В. Ющенку, де попросили продемонструвати рішучість в якості очільника держави щодо зміцнення прав та свободи слова у країні шляхом скасування політичної цензури.

У 2008 р. у відкритому листі до Президента В. Януковича генеральний секретар організації Жан-Франсуа Жульяр заявив: «Ми сподіваємося, що ваш уряд буде робити все, щоб забезпечити журналістам сприятливі умови, які є нормальними в демократичній країні, тим більше, що Україна $є$ членом Ради Європи. «Репортери без кордонів» також хотіли б нагадати вам про повагу до журналістів й висвітлення ними свободи слова» [1].

Йдеться про те, що впродовж останніх років в Україні політична цензура стала реальною дійсністю функціонування мас-медійного простору нашої держави.

У 2012 р. на першому читанні було оголошено законопроект В. Журавського про кримінальну відповідальність за наклеп. «Репортери без кордонів» знову звернулися до парламентарів України, відхилити пропозицію, твердячи, що, «...згідно з європейськими стандартами, покарання має бути адекватним і покарання у вигляді в’язниці за неправдиву інформацію - це явне перебільшення. Воно призведе до самоцензури журналістів, зупинить вільний обіг думок і фактів, а відтак позначиться на розвитку демократії в країні» [1]. Після чого, «Репортери без кордонів» у відповідь отримали листа з коментарями посла України із співпраці з міжнародними організаціями та громадянським суспільством $Є$. Перебийноса, який роз'яснював ситуацію.

У квітні 2013 р. РБК засуджують раптові зміни керівництва опозиційного телеканалу «TVi»: «...Ми шоковані діями нового керівництва незалежної телекомпанії, настійно закликаємо його не утискати дії своїх працівників, використовуючи особисті суперечки. Просимо гарантувати редакційну незалежність журналістським розслідуванням... Стурбовані відсутністю фінансової прозорості певних власників 3МІ в Україні і збільшення концентрації власності в руках влади, яка не гарантує висвітлення свободи слова у наданні новин та інформації» [1]. 
Так, у 2013 р. в Індексі свободи преси Україна опустилася ще на 10 позначок, і зараз посідає 126 місце з 179 країн [6].

Однак найсерйознішим виявом політичної цензури проти українських журналістів за останні роки стало фізичне насильство. Сьогодні в Україні зареєстровано випадки застосування проти представників 3МІ методів кримінального впливу, пов'язані з їхньою професійною діяльністю. Найбільш поширеними засобами тиску на журналістів залишаються фізичне насильство або погрози з метою змусити припинити, або обмежити журналістську діяльність. I це здійснюється, на жаль, за умов бездіяльності вітчизняної системи правозахисту.

Причиною бездіяльності українських ЗМІ полягає в тому, що вони організаційно, фінансово та кадрово залежать від органів влади, які здійснюють необмежене цензурування їхньої діяльності. Йдеться про те, що держава залишила за собою контроль над значним сегментом інформаційного простору країни.

MBC порушило п'ятнадцять кримінальних справ за фактом загибелі журналістів. В окремих випадках слідство швидко доходило висновку, що криміналу немає, і закривали справи. Генеральна прокуратура України двічі перевіряла законність і вмотивованість таких рішень і підтвердила, що все відбувалося в межах закону: якщо не було підстав вважати, що відбулося вбивство, то ніхто й не трактував нещасний випадок як розправу за професійну діяльність [4].

Всі ці факти і приклади, безперечно, свідчать про наявність в Україні політичного втручання у діяльність засобів масової інформації та журналістів, оскільки таке втручання здійснюється у політичних цілях та за участю влади.

Оцінюючи ситуацію зі свободою слова в державі за 2013 р., завідувачка секції «Європа» організації «Репортери без кордонів» С. Блатманн у звіті щодо України зазначила, що ситуація у країні залишається тривожною. Дедалі більше впливові мас-медіа контролюються або близькими до президента особами, або олігархічними структурами. I це $\epsilon$ неабиякою проблемою. Друга тенденція, яку відзначили «Репортери без кордонів», - велика кількість журналістів, які стали жертвами нападів під час розслідування ними справ, пов'язаних з корупцією на регіональному рівні.

Основними методами цензури в Україні є: пряма цензура, тобто цензурування змісту інформаційних програм та друкованих матеріалів; кримінальні злочини проти журналістів; перешкоджання здійсненню представниками 3МІ своїх професійних обов'язків; тиск на пресу з боку органів державної влади та місцевого самоврядування; створення нерівних умов конкуренції на ринку засобів масової інформації; висунення та реалізація невмотивованих судових позовів 
до ЗМІ з вимогою грошової компенсації моральної шкоди чи шкоди діловій репутації на необгрунтовано великі суми.

\section{Висновки}

Для України стає надзвичайно важливою європейська політика сусідства, яка полягає в тому, щоб скористатися перевагами розширення та зміцнити стабільність, безпеку й свободу слова. Визначені обома сторонами пріоритетні завдання ввійшли до спільного плану дій. Його виконання наблизить Україну до свободи інформації. Для держави важливо, яку роль у цьому процесі відіграватимуть ЗМІ. Адже від того, настільки якісно українські ЗМІ виконуватимуть функцію інформування, висвітлюючи сучасні інтеграційні процеси, залежить не тільки її подальша позиція у індексі свободи, а й сукупність цінностей системи українського суспільства в цілому.

\section{ЛITЕРАТУРА}

1. Reporters Without Borders [Електронний ресурс]. Режим доступу: https://en.rsf.org

2. Голованова Г. А. Средства массовой информации США, Великобритании, Франции в 1999 году [Текст] / Г. А. Голованова, Г. А. Любимов, Б. В. Шарончикова // Вестник Московского университета. Сер.10. Журналистика. - 2000. №5. - С. 59-64 : табл. - (Зарубежния журналистика). - Библиогр.: в тексте

3. Павликова М. М. Сколько лет «новой журналистике»? / М. М. Павликова // Вестн. Моск. ун-та. Сер. Журналистика. - 2000. - №1. - С. 245-247.

4. Приступенко T. О. Конституційні права та правові гарантії забезпечення свободи слова в Україні / Т. О. Приступенко [Електронний ресурс]. Режим доступу: http:// journlib.univ.kiev.ua/index.php?act=article\&article $=1607$

5. Смирнов А.Ю. Свобода слова по-французски: либеральное движение в епоху Реставрации (окончание) / А.Ю. Смирнов // Знание. Понимание. Умение. - М., 2005. - С. 152-156.

6. Ситуація зі свободою слова в Україні - найгірша з часів Помаранчевої революції [Електронний ресурс]. Режим доступу: http://nt.ck.ua/index.php/ blog-novini-svitu/4109-situacija-zi-svobodoju-slova-v-ukraïni-najgirsha-z-chasivpomaranchevoï-revoljuciï.html

\section{REFERENCES}

1. Reporters Without Borders. Retrieved from https://en.rsf.org/ (in English).

2. Golovanova, G. A., Ljubimov G. A., Sharonchikova B. V. (2000). Sredstva massovoj informacii SShA, Velikobritanii, Francii v 1999 godu [Mass media of the USA, Great Britain, France in 1999]. (Vol. 10). Moscow: Bulletin of Moscow University, Journalism, №5, pp. 59-64 (in Russian).

3. Pavlikova, M. M. (2000). Skol'ko let «novoj zhurnalistike»? [How old is «new journalism»?]. Moscow: Bulletin of Moscow University, Journalism, №1, pp. 245-247 (in Russian).

4. Prystupenko, T. O. (N. d.). Konstytutsiini prava ta pravovi harantii zabezpechennia svobody slova v Ukraini [Constitutional rights and legal guarantees of speech freedom in Ukraine]. Retrieved from http://journlib.univ.kiev.ua/index. php?act=article\&article=1607/ (in Ukrainian).

5. Smirnov, A. Ju. (2005). Svoboda slova po-francuzski: liberal'noe dvizhenie v epohu Restavracii (okonchanie): Znanie. Ponimanie. Umenie [Speech freedom in French: the liberal movement in the Restoration era (ending): Knowledge. Understanding. Skill]. Moscow: (N. p.), pp. 152-156 (in Russian). 
6. Sytuatsiia zi svobodoiu slova v Ukraini - naihirsha z chasiv Pomaranchevoi revoliutsii [The situation with speech freedom in Ukraine is the worst since the Orange Revolution]. Retrieved from http://nt.ck.ua/index.php/blog-novini-svitu/4109situacija-zi-svobodoju-slova-v-ukraïni-najgirsha-z-chasiv-pomaranchevoï-revoljuciï. html/ (in Ukrainian).

\title{
INFORMATION ACTIVITY OF THE INTERNATIONAL ORGANIZATION “REPORTERS WITHOUT BORDERS” IN UKRAINE
}

\author{
Handziuk Vitalii, \\ Candidate of Sciences (Social Communications), Associate professor \\ Vinnytsia, M. Kotsiubynskyi State Pedagogical University \\ 32 K. Ostrozkyi str. \\ 21001, Vinnytsia, Ukraine \\ e-mail:vgandz@i.ua \\ ORCID ID 0000-0002-4312-6848
}

The author of the article treats the freedom of the press as one of important guaranties of information security as it provides the access of citizens to full, all-sided and truthful information, defends public and individual consciousness from propaganda influence and other forms of manipulation, stimulates accumulation, renovation and your transmission of information within social system.

The position of key countries of the world concerning the problem of freedom of speech securing by legislative regulation is clarified; information activity and conceptual grounds for functioning of non-governmental international organization "Reporters without borders" in Ukraine are analyzed.

The author of the article also analyzes the principal methods of censorship in Ukraine: direct censorship, that is censoring the content of information programs and published materials: censoring crimes against journalists; preventing mass media representatives from fulfilling their professional duties; exerting pressure upon the press by state power bodies and local self-governments; creating unequal competition conditions in mass media market; prosecuting unmotivated suits against mass media in law courts with the demand of financial compensation for moral detriment or damage to business reputation for groundlessly enormous sums. Author's special attention is paid to the pressure on free mass media, threats to life and health of journalists according to information data of "Reporters without Borders" organization .Physical violence remains the gravest manifestation of censorship against Ukrainian journalists . In Ukraine there are registered cases of criminal methods of influence against mass media representatives, connected with their professional activities. The most widely used methods of pressure on journalists are threats, aimed at cessation or limitation of journalistic activities. And it takes place, unfortunately, under conditions of passivity of Ukrainian system of human rights defense.

In conclusions the author of the article proves the importance of the development of stability and freedom of speech security within the framework of European policy.

Further development of democratic state at large depends on high-grade carrying-out the function of informing people by Ukrainian mass media.

Key words: freedom of speech, democratic society, information activity, "Reporters without Borders". 